\title{
Habitat selection of semi-free ranging European bison: Do bison preferred natural open habitats?
}

\author{
Miloslav Zikmund, Miloš Ježek*, Václav Silovský, Jaroslav Červený \\ Czech University of Life Sciences Prague, Faculty of Forestry and Wood Sciences, Kamýcká 129, CZ-165 21 Praha, Czech Republic
}

\begin{abstract}
European bison (Bison bonasus) were successfully reintroduced in many free or semi-free areas across Europe during the last decades. Due to the increased numbers, the conflicts between human activities and bison are more frequent. Therefore the knowledge about spatial activity and habitat preference in new regions is the need for management decision making. We studied daily and seasonal habitat use of the semi-free European bison herd in the Czech Republic from 2014 to 2019. The lead cows of the herd were collared with the GPS devices with a 30-minutes GPS fixes interval. The bison herd strongly preferred the managed open areas and supplementary feeding stations during the seasons (Jacob's index from 0.49 to 0.99 ). On the contrary, they avoided the forest type and unmanaged open habitats (Jacob's index from -0.23 to -0.69 ). The managed meadows and feeding places they used almost exclusively during the night while the forest during the day-light.
\end{abstract}

Key words: habitat preference; Jacob's index; forest, open areas; feeding station

Editor: Bohdan Konôpka

\section{Introduction}

The European bison is the largest wild ungulate on the European continent (Ramos et al. 2016). At the end of the 19th century, it was on the verge of extinction, but thanks to a successful reintroduction programme, more than 40 wild yet geographically separated populations currently live in Europe (Raczynski 2019). Due to the fact that the European bison is introduced to new areas and different types of environments, there is still a lack of a unified view of its habitat preferences and what its natural environment is. The European bison is considered a species that prefers a forest environment (Plumb et al. 2009; Bleier et al. 2012; Hofman-Kamińska \& Kowalczyk 2012). However, the reason may be that the European bison is an example of a species that has been forced to move into the forest due to a combination of overgrowth of open areas after the last postglacial period and increasing human pressure on it (Cromssigt et al. 2012; Kerley et al. 2012). Based on these assumptions and the fact that the European bison needs a large amount of herbaceous vegetation each day, in recent years the bison has been very often introduced to places where it should serve as one of the species naturally farming open grassy and bushy succession habitats. In these types of vegeta- tion, the European bison should prevent the spread and development of shrubs and trees and thus maintain these areas (Jirků \& Dostál 2020). The presence of the European bison in these semi-wild farms has a significant effect on the species structure of habitats (Dostál et al. 2012). This is often the reason for the so-called rewilding concept, which assumes the reintroduction of species that have disappeared from the landscape or species farmed with the aim of increasing biodiversity without the need for active human management. This idea also often includes the reintroduction of the European bison in many areas of Central and Eastern Europe, namely Germany, Poland, Lithuania and Latvia. Where several highly suitable regions large enough to support a new herd were found, with the optimal areas being in Poland, the European bison was introduced in this way (Lord et al. 2020). Usually, semi-wild breeding is significantly limited (fenced) in space, however, with the ambition of spreading the European bison into the wild. And as like in the case of open landscape, habitat preferences may be different. This can be reflected in the resulting impact on different types of habitats. Therefore, we decided to evaluate the habitat preferences of European bison herds bred in semi-wild breeding in the Czech Republic. 


\section{Material and methods}

\subsection{Study area}

Židlov is a nature reserve with an approximate area of 38 $\mathrm{km}^{2}$ and is one of the largest fields in Central Europe. It is located in the northern part of the Czech Republic and was established in 2000 on the territory of a former military training ground. $55 \%$ of the area is occupied by commercial forests, of which $88 \%$ are conifers (pine, spruce) and $12 \%$ deciduous trees (birch, oak). The rest of the area (38\%) consists of former impact areas that have been left to natural succession and currently form a foreststeppe landscape with a predominance of unmaintained grasses, pioneer trees and shrubs. Cultivated agricultural land occupies $5 \%$ and consists of maintained meadows used for grazing game. In the nature reserve there are red deer, fallow deer, mouflon, roe deer, and wild boar. Since 2011, European bison, which have been imported from Białowieża Forest and Kampinos National Park, have been bred in the nature reserve. Currently, there is a herd of a total of 34 European bison in the nature reserve (Raczyński 2019). Since 2014, wolves that are able to overcome fencing occasionally occur in the nature reserve.

\subsection{Data collection}

Between 2014 and 2018, the movement of the European bison herd was monitored with a telemetry collar (VECTRONIC Aerospace GmbH; type GPS Plus 5D). The sampling frequency of GPS positions was 30 minutes (Červený et al. 2014). GPS data were used according to the method of Lewis et al. (2007), and all positions with DOP less than 6 were not used in the analyzes due to high inaccuracy of measurement. A total of 23,000 positions were available.

Information about the environment comes from the mapping itself, when on the basis of field walks the area was vectorized and habitats were divided into the following main types: Meadow, Bush, Forest, Feeding places. Meadow is a grassland economically maintained and restored, which is used to graze game kept in the nature reserve. Bush is formed by stands of early successional stages, which are gradually overgrown with shrubs and trees; these stands are not maintained. Forests are commercial forests used for wood production. Feeding places are places where supplementary feed (grain, corn, hay, haylage) is presented to game throughout the year. An area with a radius of 100 meters from the feeding facility was defined as a feeding place.

\subsection{Statistical analyses}

Occurrence and habitat data were processed in ArcGIS 10.7 software (ESRI 2010). The spatial join tool was used to link bison herd data and habitat type.
The Jacob's index was used to determine habitat preferences. The Jacob's index was calculated according to the formula:

$$
D=(r-p) /(r+p-2 r p),
$$

where $r$ is the proportion of habitat used and $p$ the proportion of habitat available. D varies from -1 (strong avoidance) to +1 (strong preference), and values close to zero indicate that the habitat is used in proportion to its availability (Jacobs 1974; Kauhala and Aittilla 2008).

Data normality was tested using the one-sample Kolmogorov-Smirnov test. If the distribution was not normal, a nonparametric test was used to compare the data. For the Jacob's index, 95\% confidence intervals were calculated to find the difference in different parts of the year.

The data were divided according to the time distribution in the year, either according to calendar months or seasonality for spring (March, April, May), summer (June, July, August), autumn (September, October, November) and winter (December, January, February).

The Oriana 4.02 software (Kovach Computing) and circular statistics were used to examine the distribution of habitat preference during the 24-hour cycle (Lehner 1996). Significant deviations from random distributions were investigated using the Rayleigh test of circular statistics.

\section{Results}

On average across the entire time period, the European bison herd used forest type (34\%), feeding places (23\%), meadow (22\%) and bush (21\%). However, habitat use varied significantly between seasons (Kruskal-Wallis Anova, $\mathrm{p}<0.000$; Fig. 1). Forest stands were mostly used by bison in summer (47\%) and least in autumn (20\%), feeding places mostly in winter (58\%) and least in summer (3\%), meadows mostly in summer (33\%) and least in winter (5\%), and bush most in summer (23\%) and least in winter $(15 \%)$.

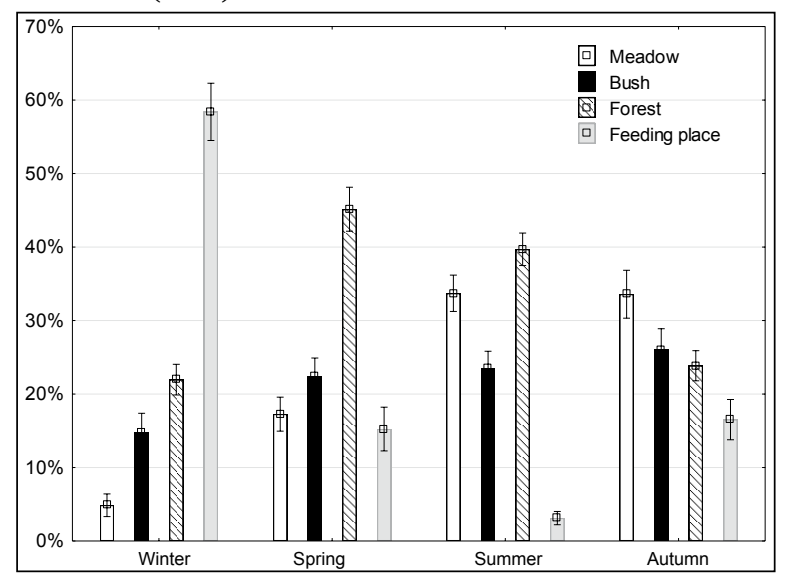

Fig. 1. Habitat utilization of bison during the seasons (\% of total location in the season) for different type of habitat (column $=$ mean; whisker $=$ mean \pm 0.95 conf. interval). 
As for the preferences in individual seasons (Fig. 2 and Table 1), the largest Jacob's index showed a bison herd for feeding places in winter (0.98), spring (0.87), autumn (0.86), only in summer the preference slightly decreased (to 0.41). Another type of vegetation that European bison strongly preferred were cultivated meadows. In spring the Jacob's index was 0.49 , in summer 0.76 , in autumn 0.70 . Only in winter the index fell to -0.14 . On the contrary, the European bison did not prefer, or even deliberately avoided the forest and bush. The Jacob's index for the forest ranged from -0.69 in the fall to -0.23 in the spring. It was similar for bush, when the index took values from -0.49 in winter to -0.26 in spring.

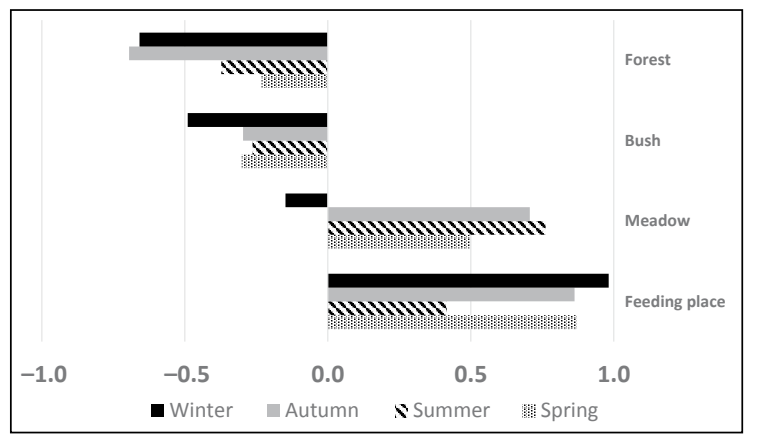

Fig. 2. Habitat preference of bison during the seasons (Jacob's index) for different type of habitat.

Table 1. Values of Jacob's index for month's and different type of habitat.

\begin{tabular}{lcccc}
\hline & Feeding place & Meadow & Bush & Forest \\
\hline January & 0.99 & -0.42 & -0.71 & -0.67 \\
February & 0.96 & -0.11 & -0.23 & -0.53 \\
March & 0.96 & 0.36 & -0.36 & -0.49 \\
April & 0.77 & 0.53 & -0.28 & -0.15 \\
May & 0.00 & 0.57 & -0.27 & -0.05 \\
June & 0.56 & 0.73 & -0.22 & -0.34 \\
July & -0.01 & 0.79 & -0.31 & -0.33 \\
August & 0.48 & 0.78 & -0.24 & -0.41 \\
September & 0.78 & 0.79 & -0.21 & -0.55 \\
October & 0.86 & 0.77 & -0.17 & -0.61 \\
November & 0.94 & 0.72 & -0.19 & -0.73 \\
December & 0.99 & 0.02 & -0.52 & -0.75 \\
\hline
\end{tabular}

The distribution of habitat use also shows statistically significant differences (Table 2). In winter, when the differences in preference according to the Jacob's index are greatest, European bison primarily use feeding places and meadows during the night, while forest almost exclusively during the day. Bush, on the other hand, is used during dawn (Fig. 3). At the same time, in meadows and forests there is a very high value of the mean length of the vector and the concentration of data in the preferred parts of the day throughout the year. With the exception of spring, the values of bushes are very low and the significance is also an order of magnitude lower than for other types of stands.

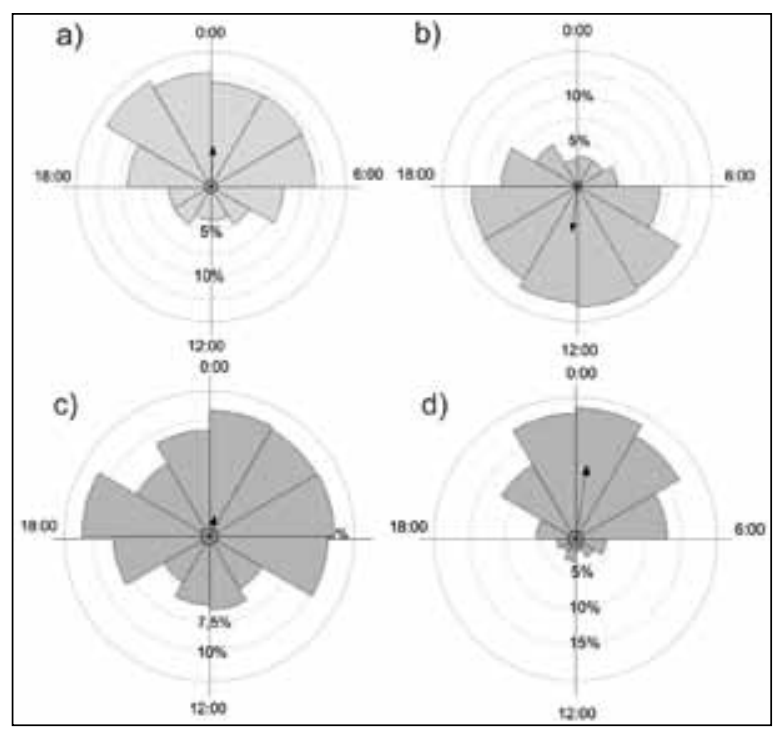

Fig. 3. Daily habitat selection during the spring: a) bush; b) forest; c) feeding place; d) meadow.

\section{Discussion}

The high preference of the forest corresponds to the results found in other studies. As reported by Bleier et al. (2012) or Hofman-Kamińska and Kowalczyk (2012), the European bison prefer forest type environments, especially during daytime (Červený et al. 2014; Marozas et al. 2019). Conversely, at night, European bison prefer open stands (Pucek et al. 2004; Daleszcyk et al. 2007; Marozas et al. 2019). This corresponds to the theory that bison changed their behaviour after the last postglacial period,

Table 2. Circular statistics values for daily use of different type of habitat and season.

\begin{tabular}{|c|c|c|c|c|c|}
\hline & & Spring & Summer & Autumn & Winter \\
\hline \multirow{3}{*}{ Feeding place } & Concentration & 0.305 & 0.429 & 0.28 & 0.333 \\
\hline & Rayleigh Test (p) & $<0.001$ & $<0.001$ & $<0.001$ & $<0.001$ \\
\hline & Mean vector & $00: 35$ & $0: 58$ & $00: 22$ & $02: 33$ \\
\hline \multirow{3}{*}{ Meadow } & Length of Mean Vector (r) & 0.5423 & 0.486 & 0.412 & 0.200 \\
\hline & Concentration & 1.222 & 1.109 & 0.904 & 0.409 \\
\hline & Rayleigh Test (p) & $<0.001$ & $<0.001$ & $<0.001$ & $<0.001$ \\
\hline \multirow[t]{3}{*}{ Forest } & Concentration & 0.719 & 1.033 & 1.179 & 1.046 \\
\hline & Rayleigh Test (p) & $<0.001$ & $<0.001$ & $<0.001$ & $<0.001$ \\
\hline & Mean vector & $00: 11$ & $00: 06$ & $20: 37$ & $19: 14$ \\
\hline \multirow{3}{*}{ Bush } & Length of Mean Vector (r) & 0.299 & 0.099 & 0.035 & 0.092 \\
\hline & Concentration & 0.628 & 0.199 & 0.069 & 0.184 \\
\hline & Ravleigh Test (p) & $<0.001$ & $<0.01$ & $<0.01$ & $<0.01$ \\
\hline
\end{tabular}


which was associated with a decrease in open areas and increasing activity of people for whom European bison were prey (Cromssigt et al. 2012; Kerley et al. 2012). Their frequent stay in open areas during the night can also be the result of better grazing, when, like other ruminants, they look for richer food habitats at a time when they are less disturbed by humans (Whittaker \& Knight 1998). This is also confirmed by conclusions about the type of habitat preference. In most cases within our study these were maintained grasslands, regularly managed. Their share in the total area is only $5 \%$, but bison occur in it up to $33 \%$ of the total time of day (Summer). Other natural successive shrub formations (Bush) are avoided throughout the year, even though they make up more than $43 \%$ of the total area. On average, they spend only $21 \%$ of their total time on them. In other studies, European bison similarly preferred cultivated farmland. E.g. in Lithuania (Marozas et al. 2019), European bison spent up to $56 \%$ of their time at night there, of which only $7 \%$ on the uncultivated land to which we can compare bush. On the contrary, they significantly preferred qualitatively rich types of vegetation, such as rape or cereals. European bison living on the borders of the Białowieża National Park showed similar preferences, when their home districts intervened in the agricultural landscape. This also supports the findings of Mendoza and Palmquist (2008), who rank the bison morphologically among the species adapted to live in rich grass communities. On the contrary, the results of food analyses carried out in the central part of the Białowieża National Park, where neither feeding is carried out nor cultivated agricultural crops are present, suggest that European bison prefer highly nutritious and easily digestible parts of woody plants, shrubs and herbs to grasses (Kowalczyk et al. 2019). At the same time, they also point out that the content of graminoids (which contain a large percentage of grasses) was higher, especially in the period when the supply of quality trees and shrubs was declining. This indicates a high degree of plasticity of the bison in food selection and they can thus be described as a generalist (Freeland 1991), where this type of animal prefers high quality food and is only selective if its presence in the environment is high.

The theory of the European bison as a generalist is also supported by the high intensity of the use of feeding places, which in our study achieved very high preferences (Winter Jacob's index =1), and where the bison spent up to $60 \%$ of the day in their immediate vicinity $(<100 \mathrm{~m})$.

Such a high preference for feeding sites can cause a significant reduction in flight distance and also to attraction by strengthening an animal's behavior through positive reinforcement and encouraging movement towards a stimulus (Haidt et al. 2018). Bisons aggregation by feeding sites may facilitate transmission of nematode Ashworthius sidemi, which occurs by ingesting an invasive larval stage (Radwan et al. 2010; Vadlejch et al. 2017).

\section{Conclusion}

We conclude that bison highly preferred the managed open habitats (meadows) and feeding sites all year around. The forest habitats bison use usually during the daylight which is related to antipredation behavior. In contrary they avoid the opened unmanaged succession areas. This can cause conflicts between the humans and bison interests. It's also necessary to consider the relationship with other game species because of the high preference for feeding stations by bison. This can cause that other species will have limited access to these places.

In the case of bison reintroduction in areas with intensively cultivated agricultural areas, it is appropriate to cultivate a special pasture areas for it and thus eliminate possible migration outside the core area and prevent damages and conflicts. A very common goal of bison reintroduction is to eliminate woody plants and other aggressive species of plant on the open succession areas by bison grazing. However, this purpose proves to be unsuitable for large semi free areas or in the freerange areas. It is suitable to implement it only in small limited farms, where the bison has a limited choice of habitat and food sources. To establish the management plans and true decision making policy, a detailed study of habitat preferences is suitable, especially in areas newly inhabited by bison.

\section{Acknowledgements}

This study was supported by grants QK1910462 of the Ministry of Agriculture and B_19_02 of FFWS.

\section{References}

Bleier, N., Lehoczki, N., Újváry, D., Szemethy, L., Csány, S., 2012: Relationships between wild ungulates density and crop damage in Hungary. Acta Theriologica, 57:351-359.

Cromsigt, J. P. G. M., Kerley, G. I. H., Kowalczyk, R., 2012: The difficulty of using species distribution modeling for the conservation of refugee species-the example of European bison. Diversity and Distributions, 18:1253-1257.

Červený, J., Ježek, M., Holá, M., Zikmund, M., Kušta, T., Hanzal, V., Kropil, R., 2014: Daily activity rhythm and habitat use of the semi-free European bison herd during the growing season. Lesnícky časopis - Forestry Journal, 60:199-204.

Daleszczyk, K., Krasińska, M., Krasiński, Z. A., Bunevich, A. N., 2007: Habitat structure, climatic factors, and habitat use by European bison (Bison bonasus) in Polish and Belarussian parts of the Białowiez' a Forest, Poland. Canadian Journal of Zoology, 85: 261-272. 
Dostál, D., Jirků, M., Konvička, M., Čížek, L., Šálek, M., 2012: Návrat zubra evropského (Bison bonasus) do České republiky. Česká krajina, Kutná Hora, 120 p.

Freeland, W. J., 1991: Plant secondary metabolites: biochemical coevolution with herbivores. Plant defenses against mammalian herbivory. CRC Press, Boca Raton, p. 61-81.

Haidt, A., Kamiński, T., Borowik, T., Kowalczyk, R., 2018: Human and the beast - Flight and aggressive responses of European bison to human disturbance. PLOS ONE, 13:e0200635.

Hofman-Kamińska, E., Kowalczyk, R., 2012: Farm Crops Depre-dation by European Bison (Bison bonasus) in the Vicinity of Forest Habitats in Northeastern Poland. Environmental Management, 50:530-541.

Jacobs, J., 1974:. Quantitative measurement of food selection. Oecologia, 14:413-417.

Jirků, M., Dostál, D., 2020: Zhodnocení managementu bezlesí VVP Milovice-Mladá přirozenou pastvou velkých kopytníků 2015 - 2019. Praha, 25 p.

Kauhala, K., Auttila, M., 2010: Estimating habitat selection of badgers-a test between different methods. Journal of Vertebrate Biology, 59:16-25.

Kerley, G. I. H., Kowalczyk, R., Cromsigt, J. P. G. M. 2012: Conservation implications of the refugee species concept and the European bison: king of the forest or refugee in a marginal habitat? Ecography, 35: 519-529

Kowalczyk, R., Wójcik, J. M., Taberlet, P., Kamiński, T., Miquel, Ch., Valentini, A. et al., 2019: Foraging plasticity allows a large herbivore to persist in a sheltering forest habitat: DNA metabarcoding diet analysis of the European bison. Forest Ecology and Management, 449:117474.

Lehner, P. N., 1996: Spatial orientation and time: circular statistics and spatial patterns. In: Lehner, P. N. (ed.): Handbook of ethological methods. Cambridge University Press, p. 485-521.

Lewis, J. S., Rachlow, J. L., Garton, E. O., Vierling, L. A., 2007: Effects of habitat on GPS collar performance: using data screening to reduce location error. Journal of Apply Ecology, 44:663-671.
Lord, C. M., Wirebach, K. P., Tompkins, J., BradshawWilson, C., Shaffer, Ch. L., 2020: Reintroduction of the European bison (Bison bonasus) in central-eastern Europe: a case study. International Journal of Geographical Information Science, 34:1628-1647.

Marozas, V., Kibiša, A., Brazaitis, G., Jõgiste, K., Šimkevičius, K., Bartkevičius, E., 2019: Distribution and Habitat Selection of Free-Ranging European Bison (Bison bonasus L.) in a Mosaic Landscape-A Lithuanian Case. Forests, 10:339-345.

Mendoza, M., Palmqvist, P., 2008: Hypsodonty in ungulates: an adaptation for grass consumption or for foraging in open habitat? Journal of Zoology, 274: 134-142.

Plumb, G.E., White, P.J., Coughenour, M. B., Wallen, R. L., 2009: Carrying capacity, migration, and dispersal in Yellowstone bison. Biologicall Conservation, 142: 2377-2387.

Pucek, Z., Belousova, I. P., Krasińska, M., Krasiński, Z. A., Olech, W., 2004: European bison. Status survey and conservation action plan. IUCN/SSC Bison Specialist Group. IUCN, Gland, Switzerland.

Raczyński, J., 2019: European bison pedigree book. Białowieski Park Narodowy, 100 p.

Radwan, J., Demiaszkiewicz, A. W., Kowalczyk, R., Lachowicz, J., Kawalko, A., Wojcik, J. M.et al., 2010: An evaluation of two potential risk factors, MHC diversity and host density, for infection by an invasive nematode Ashworthius sidemi in endangered European bison (Bison bonasus). Biological Conservation, 143:2049-2053.

Ramos, A., Petit, O., Longour, P., Pascuarett, C., Sueur, S., 2015: Collective decision making during group movements in Europea bison (Bison bonasus). Animal Behavior, 109:149-160.

Ramos, A., Petit, O., Longour, P., Pasquaretta, C., Sueur, C., 2016: Space use and movement patterns in a semi-free-ranging herd of European bison (Bison bonasus). PloS One, 11:e0147404.

Vadlejch, J., Kyriánová, I. A., Rylková, K., Zikmund, M., Langrová, I., 2017: Did European bison conservation program introduced an alien parasite to the Czech Republic? Biological Invasions, 19:1121-1125.

Whittaker, D., Knight, R. L., 1998: Understanding wildlife responses to humans. Wildlife Society Bulletin, 26:312-317. 